EUROPA REGIONUM TOM XXIII ROK 2015

DOI: $10.18276 /$ er.2015.23-08

WŁODZIMIERZ DELUGA

Politechnika Koszalińska

\title{
Wybrane aspekty wykorzystania marketingu ekologicznego dla poprawy środowiska naturalnego w Koszalinie
}

\section{Wprowadzenie}

J okalne samorządy i jednostki komunalne coraz częściej postrzegają zarządzanie środowiskowe jako możliwość zmniejszenia obciążenia środowiska przyrodniczego, obniżenia kosztów funkcjonowania, wzrostu efektywności czy poprawienia swojego wizerunku. W realizację zarządzania środowiskiem wpisuje się marketing ekologiczny, który podkreśla relacje i zależności występujące pomiędzy człowiekiem, społeczeństwem i środowiskiem naturalnym.

Środowisko przyrodnicze ma wpływ na rozwój gospodarczy różnych dziedzin ludzkiej aktywności, w tym branży turystycznej. Uzależnia się budowę i rozwój infrastruktury turystycznej w zależności od stopnia aktywności społecznej na rzecz ochrony środowiska czy stopnia społecznej akceptacji zasad ekorozwoju.

Celem niniejszego artykułu jest podkreślenie roli marketingu ekologicznego w pobudzaniu inicjatyw proekologicznych i kształtowaniu świadomości ekologicznej społeczeństwa.

\section{Istota marketingu ekologicznego}

Jedną z przyczyn zachodzących zmian jest wzrastające antropogenne zagrożenie środowiska przyrodniczego. Zarządzanie środowiskiem oznacza zarządzanie użytkowaniem, ochroną i kształtowaniem środowiska. 
Rozważając problematykę marketingu ekologicznego należy zapoznać się z takimi pojęciami jak: ekologia, ekologia społeczna, świadomość ekologiczna oraz tematyka marketingu społecznego.

Pojęcie „ekologia” pochodzi z języka greckiego od słów „oikos” - dom i „logos” - wiedza, nauka. Ekologia jest nauką, która zajmuje się strukturą oraz funkcjonowaniem przyrody, a także skupia się na badaniu wzajemnych relacji występujących pomiędzy organizmami a ich żywym i martwym środowiskiem ${ }^{1}$. W języku potocznym termin „ekologia” stosowany jest bardzo często jako definicja ochrony środowiska lub nauki o ochronie środowiska. Jest to błędne określenie, ponieważ nauką o ochronie środowiska jest sozologia.

Ekologia społeczna według Encyklopedii Naukowej PWN to ,dyscyplina naukowa z pogranicza biologii, socjologii, geografii, badająca związki między przestrzennym układem zjawisk społecznych a ich charakterem”. Ekologia społeczna bada więc zależności występujące pomiędzy człowiekiem, społeczeństwem i środowiskiem naturalnym. Pogląd ten ma na celu kształtowanie relacji pomiędzy społeczeństwem a przyroda, czyli zwrócenie uwagi na sposoby przeciwdziałania degradacji środowiska, zwiększenie odpowiedzialności człowieka za środowisko oraz na kształtowanie świadomości ekologicznej społeczeństwa.

Świadomość ekologiczna to ,stosunek człowieka do środowiska przyrodniczego, zespół informacji i przekonań na jego temat, a także system wartości, jakim ta osoba kieruje się wobec niego w swoim postępowaniu"”.

Aktualnie można się spotkać z dwoma definicjami marketingu społecznego: w wąskim oraz pełnym wymiarze. Definicja w wąskim wymiarze wskazuje na to, że marketing społeczny jest formą działalności, która polega na tym, że organizacja przeznacza część swojego zysku na wspieranie z góry określonej sprawy ${ }^{3}$.

Druga definicja marketingu społecznego odnosi się do przedsiębiorstw, które problemy społeczne traktują w sposób całościowy, z uwzględnieniem własnego oddziaływania. W takim ujęciu marketing społeczny polega na określeniu potrzeb, wymagań oraz interesów rynków docelowych, a następnie dostarczenie pożądanego zadowolenia w sposób bardziej efektywny i wydajny niż konkurenci, przy jednoczesnym zachowaniu lub podniesieniu dobrobytu konsumenta i społeczeństwa ${ }^{4}$.

${ }^{1}$ K. Małachowski, Spoteczne aspekty ochrony środowiska, w: Gospodarka a środowisko i ekologia, red. K. Małachowski, CeDeWu, Warszawa 2011, s. 29.

${ }_{2}^{2}$ D. Kiełczewski, Ekologia społeczna, Wydawnictwo Ekologia i Środowisko, Białystok 1999, s. 20.

${ }^{3}$ K. Przybyłkowski, Marketing, Dom Wydawniczy ABC, Warszawa 1998, s. 499.

${ }^{4} \mathrm{Ph}$. Kotler, Marketing. Analiza, planowanie, wdrażanie i kontrola, Gebethner i S-ka, Warszawa 1994, s. 26. 
W ramach wyżej opisanego marketingu społecznego wyróżnia się m.in. marketing odpowiedzialny ekologicznie, zwany też marketingiem ekologicznym, zielonym marketingiem, ekomarketingiem lub marketingiem środowiskowym ${ }^{5}$.

J. Leśniak stwierdza, iż „,marketing ekologiczny to proces zarządzania mający na celu rozpoznawanie i prognozowanie potrzeb konsumentów w zakresie proekologicznych wyrobów i usług i zaspokajanie ich poprzez kreowanie podaży wyrobów i usług przyjaznych dla środowiska naturalnego oraz informowanie konsumentów i producentów o ekologicznych cechach produktów"6.

Głównym zadaniem marketingu ekologicznego jest odpowiedź na proekologiczne potrzeby konsumentów. Do głównych potrzeb proekologicznych można zaliczyć:

- troskę o czyste powietrze, glebę oraz zbiorniki wodne,

- ochronę przyrody przed degradacją,

- wzrost zainteresowania recyklingiem,

- dążenie do minimalizacji wykorzystania zasobów naturalnych oraz ich racjonalną gospodarkę,

- promowanie orientacji ekologicznej i zdrowego stylu życia ${ }^{7}$.

Rozwój marketingu ekologicznego możliwy jest dzięki uczestnikom rynku, którzy coraz bardziej interesują się sprawami dotyczącymi ochrony środowiska. $\mathrm{Z}$ jednej strony świadomość ekologiczna konsumentów wzrasta, a z drugiej strony coraz bardziej upowszechnia się koncepcja społecznie odpowiedzialnego biznesu, gdzie ważne miejsce zajmuje troska o środowisko naturalne.

Pojęcie marketingu ekologicznego wywodzi się z marketingu społecznego. Sam marketing środowiskowy jest odpowiedzią na proekologiczne potrzeby konsumentów i można go zdefiniować jako proces projektowania, wytwarzania, sprzedawania oraz reklamowania produktów, które są ukierunkowane na ochronę środowiska. Rozwój ekomarketingu jest korzystny, ponieważ nie tylko zwraca się uwagę społeczeństwa na problemy ekologiczne, ale także pomaga w rozwiązywaniu powstałych problemów

${ }^{5}$ S. Zaremba-Warnke, Pojęcie marketingu ekologicznego, w: Marketing ekologiczny, red. S. Zaremby-Warnke, Wydawnictwo Uniwersytetu Ekonomicznego we Wrocławiu, Wrocław 2009, s. 100 .

${ }^{6}$ J. Leśniak, Rola instrumentów marketingu ekologicznego we wdrażaniu rozwoju zrównoważonego na przykładzie Szwecji, w: Ekonomia a zrównoważony rozwój, t. 2, red. F. Piontek, Ekonomia i Środowisko, Białystok 2001, s. 87.

${ }^{7}$ D. Castenow, Nowy marketing w praktyce, PWE, Warszawa 1996, s. 107-108. 


\section{Stan środowiska naturalnego w Koszalinie}

Miasto Koszalin zajmuje powierzchnię $98,34 \mathrm{~km}^{2}$ i położone jest w północno-wschodniej części województwa zachodniopomorskiego. Miasto Koszalin jest miastem na prawach powiatu.

Koszalin położony jest w dorzeczu rzeki Dzięrżęcinki, w bezpośrednim sąsiedztwie jednego z największych jezior w Polsce - jeziora Jamno oraz w bliskiej odległości od Morza Bałtyckiego. Centrum miasta oddalone jest od Morza Bałtyckiego w linii prostej o ok. $6 \mathrm{~km}$. Taka lokalizacja wpływa znacząco na jego atrakcyjność turystyczną.

Miasto Koszalin stanowi ważny ośrodek komunikacyjny na mapie Polski, ponieważ przez miasto przebiegają dwie drogi krajowe: droga krajowa nr 11 łącząca Koszalin z południową częścią Polski oraz droga krajowa nr 6, która stanowi niezbędne połączenie pomiędzy dwoma największymi ośrodkami miejskimi w północnej Polsce, czyli Szczecinem i Trójmiastem. Dla Koszalina charakterystyczny jest sezonowy wzrost liczby samochodów przejeżdżających przez miasto (tranzyt osobowy i ciężarowy). Miasto Koszalin jest ważnym ośrodkiem gospodarczym i kulturalnym na Pomorzu Środkowym, jest siedzibą wielu urzędów i instytucji o znaczeniu regionalnym. Koszalin także jest ważnym ośrodkiem akademickim na Pomorzu Środkowym. W Koszalinie zamieszkuje około 110 tys. mieszkańców.

Koszalin jest dynamicznie rozwijającym się ośrodkiem przemysłowym, drugim co do wielkości w województwie. W zachodniej części miasta zlokalizowana jest Podstrefa „Koszalin” Słupskiej Specjalnej Strefy Ekonomicznej, która została utworzona w 2003 roku i obecnie na jej terenach pracuje ponad 1500 osób. $Z$ danych Głównego Urzędu Statystycznego z 2013 roku wynika, że dominującymi przedsiębiorstwami w Koszalinie są mikroprzedsiębiorstwa (ok. 97\%).

Znaczną część powierzchni miasta zajmują tereny zielone, które stanowią 38\% ogólnej powierzchni miasta. W skład systemu przyrodniczego miasta wchodzą nie tylko parki miejskie, ale także 34 zieleńce. Na terenie miasta Koszalina znajdują się dwa rezerwaty przyrody: „Bielica” - rezerwat przyrody nieożywionej oraz „, Jezioro Lubiatowskie" - rezerwat faunistyczny. Dodatkowo także w granicach administracyjnych Koszalina znajdują się 3 użytki ekologiczne: „Bagno”, „Łąka” i „Pastwisko” o powierzchni łącznej ok. 27 ha. Użytki te są objęte ochroną ze względu na unikatowy starodrzew. Na terenach tych znajduje się łącznie 59 pomników przyrody.

Miasto Koszalin jest postrzegane jako jedno z najczystszych i najbardziej zielonych miast w województwie zachodniopomorskim, chociaż stan powietrza określa 
się jako niezadowalający ze względu na podwyższony stan benzo(a)piranu, który jest niezwykle niebezpieczny dla zdrowia mieszkańców oraz środowiska naturalnego $^{8}$. Dlatego też po stwierdzeniu ponadnormatywnej emisji b(a)p, czyli benzo(a)piranu, Sejmik Województwa Zachodniopomorskiego uchwalił „Program Ochrony Powietrza Dla Strefy Miasto Koszalin".

Główną przyczyną przekroczeń dopuszczalnego poziomu benzo(a)piranu w powietrzu są procesy spalania paliw stałych, czyli (wegiel, drewno) w sektorze energetycznym, przemysłowym oraz komunalno-bytowym. Spaliny samochodowe maja niewielki udział w emisji benzo(a)pirenu. Roczna emisja benzo(a)pirenu ze strefy miasto Koszalin wyniosła $26,3 \mathrm{~kg}$, a największym źródłem są paleniska domowe, w tym piece kaflowe oraz kominki, czyli tzw. emisja powierzchniowa - 81,72\% $(21,5 \mathrm{~kg} / \mathrm{rok})$. Najmniejszy udział mają spaliny samochodowe $-0,42 \%(0,1 \mathrm{~kg} / \mathrm{rok})$.

Tabela 1

Emisja benzo(a)piranu ze strefy miasto Koszalin w 2011r.

\begin{tabular}{|l|c|c|}
\hline \multicolumn{1}{|c|}{ Typ emisji } & Benzo(a)piren $(1 \mathrm{~kg} /$ rok $)$ & Wartość wyrażona w \% \\
\hline Punktowa & 0,1 & 0,42 \\
\hline Powierzchniowa & 21,5 & 81,72 \\
\hline Liniowa & 4,7 & 17,86 \\
\hline Suma & 26,3 & 100 \\
\hline
\end{tabular}

Źródło: „Program Ochrony Powietrza Dla Stref Województwa Zachodniopomorskiego, tj. aglomeracji szczecińskiej, miasta Koszalin oraz strefy zachodniopomorskiej - TOM III - STREFA MIASTO KOSZALIN", 2013 r.

Innymi głównymi zanieczyszczeniami gazowymi emitowanymi w Koszalinie są przede wszystkim związki dwutlenku węgla, które nie stanowią co prawda zagrożenia dla ludzi, zwierząt oraz roślin, ale wpływają niekorzystnie na globalne ocieplenie oraz związki, które stanowią zagrożenie dla zdrowia: dwutlenek siarki, tlenki azotu, tlenki węgla i zanieczyszczenia pyłowe.

Główne działania naprawcze zmierzające do ograniczenia zanieczyszczenia powietrza benzo(a)piranem na terenie miasta Koszalina:

- obniżenie emisji powierzchniowej - podłączenie do miejskiego systemu ciepłowniczego mieszkań, które są ogrzewane indywidualnie (paliwo sta-

${ }^{8}$ Benzo(a)pireny są wielopierścieniowymi węglowodorami aromatycznymi (WWA), które są związkami silnie rakotwórczymi. Benzopireny są składnikiem zanieczyszczeń powietrza, powstającym w wyniku niskiej emisji. Stężenie benzopirenów w powietrzu jest jednym z parametrów oceny jakości powietrza. 
łe) lub wymiana w tych mieszkaniach sposobu ogrzewania na ogrzewanie paliwem bez-lub ... niskoemisyjnym (np. gaz, ogrzewanie elektryczne);

- edukacja ekologiczna - akcje edukacyjne mające na celu informowanie mieszkańców o szkodliwości spalania odpadów w paleniskach domowych oraz promocja innowacyjnych i niskoemisyjnych źródeł ciepła;

- zapisy w planach zagospodarowania miejskiego - stosowanie odpowiednich reguł oraz zapisów, umożliwiających ograniczenie emisji benzo(a)piranu w planach zagospodarowania miejskiego;

- zapisy w regulaminie utrzymania czystości i porządku na terenie miasta Koszalin - zakaz spalania odpadów zielonych na terenach działkowych, przydomowych oraz na terenach zieleni miejskiej.

Zagrożenie emisją hałasu jest równie niebezpieczne co zagrożenie emisją niepożądanych substancji. Na terenie Koszalina głównymi źródłami hałasu w środowisku są: komunikacja drogowa, komunikacja kolejowa oraz przemysł. Największy wpływ na klimat akustyczny miasta ma hałas drogowy, który niebezpieczny jest dla mniej niż 3\% mieszkańców. Z kolei hałasem kolejowym i przemysłowym zagrożona jest stosunkowo niewielka liczba mieszkańców $-0,1 \%$.

$\mathrm{Z}$ uwagi na przekroczenie dopuszczalnego poziomu hałasu w niektórych rejonach Koszalina, opracowano „Program Ochrony Środowiska Przed Hałasem Dla Miasta Koszalina”, którego głównym zadaniem będzie określenie działań i kierunków, których konsekwentna realizacja pozwoli na dostosowanie poziomu hałasu do obowiązujących norm.

Problem przekroczenia dopuszczalnych norm poziomu hałasu drogowego według wskaźnika $\mathrm{L}_{\mathrm{DwN}}$ dotyczy ok. 2,82\%, czyli 2947 mieszkańców Koszali$\mathrm{na}^{10}$. Dodatkowo ponadnormatywny poziom przekroczenia hałasu drogowego określony wskaźnikiem $\mathrm{L}_{\mathrm{DWN}}$ dotyczy $20,5 \%$ obiektów szkolnych i przedszkolnych oraz 4 z 10 obiektów służby zdrowia. Większość terenów zagrożonych hałasem znajduje się wzdłuż drogi krajowej nr 6.

Odpady są bardzo poważnym problemem, z którym musi się zmagać dzisiejsze społeczeństwo. Odpady są to zużyte przedmioty oraz substancje stałe i płynne, które powstają na skutek funkcjonowania człowieka oraz jego działal-

${ }^{9}$ Program Ochrony Środowiska Przed Hałasem Dla Miasta Koszalina, 2013.

${ }^{10}$ Wskaźnik $\mathrm{L}_{\mathrm{DWN}}$ : długookresowy średni poziom dźwięku wyrażony w decybelach $(\mathrm{dB})$, wyznaczony w ciaggu wszystkich pór w roku, z uwzględnieniem pory dnia (6.00-18.00), pory wieczoru $(18.00-22.00)$ oraz pory nocy $(22.00-6.00)$. 
ności gospodarczej. Odpady są nieprzydatne w miejscu i czasie, w którym powstały, a dodatkowo są uciążliwe dla ludzi oraz środowiska ${ }^{11}$.

$Z$ dniem 1 stycznia 2012 roku weszła w życie znowelizowana ustawa dotycząca utrzymania czystości i porządku w gminach. Nowe przepisy wprowadziły znaczące zmiany w gospodarowaniu odpadami komunalnymi.

W Koszalinie przyjęto następujące stawki opłat dla mieszkańców Koszalina za odbiór i zagospodarowanie odpadów:

- w przypadku nieselektywnego zbierania odpadów - 0,90 zł za $1 \mathrm{~m}^{2}$ powierzchni lokalu mieszkalnego,

- w przypadku selektywnego zbierania odpadów - 0,60 zł za $1 \mathrm{~m}^{2}$ powierzchni lokalu mieszkalnego.

Z informacji udostępnionych przez Biuro Gospodarki Odpadami Komunalnymi w Koszalinie wynika, że 93\% składających deklarację segreguje odpady. Na terenie Koszalina odpady komunalne odbierane są przede wszystkim przez Przedsiębiorstwo Gospodarki Komunalnej Sp. z o.o. Na terenie Koszalina nie ma żadnych składowisk odpadów, działa jedynie Punkt Selektywnego Zbioru Odpadów. Składowisko odpadów, na które kierowane są odpady zebrane z Koszalina, znajduje się w Sianowie. Zadowalający stan segregowania odpadów wynika nie tylko z punktu widzenia ekonomii, lecz nade wszystko ze wzrastającej świadomości ekologicznej mieszkańców.

Stan gospodarki wodno-ściekowej. Woda jest podstawowym elementem środowiska przyrodniczego, ponieważ jest niezbędna do funkcjonowania ludzi, roślin oraz zwierząt. Woda sprawuje funkcję środowiska życia, jest składnikiem pożywienia oraz bierze udział $\mathrm{w}$ przemianie materii.

W Koszalinie dostępność do wody używanej w celach użytkowych, przemysłowych i usługowych na terenie Koszalina jest zadowalająca. Obszar Koszalina zaopatrywany jest w wodę z dwóch ujęć: w Koszalinie i Mostowie. W Koszalinie działa 16 studni, w Mostowie 37. Woda na potrzeby mieszkańców Koszalina dostarczana jest obecnie za pomocą sieci wodociagowej o łącznej długości $210 \mathrm{~km}$. Z instalacji wodociagowej korzysta prawie 98\% mieszkańców, zaś z instalacji kanalizacyjnej 95\%.

Odbiorem ścieków oraz eksploatacją sieci kanalizacyjnej i oczyszczalni ścieków zajmują się podobnie jak w przypadku sieci wodociagowej Miejskie

${ }^{11}$ A. Drab-Kurowska, Zagrożenia środowiska powodowane przez działalność człowieka, w: Gospodarka a środowisko i ekologia... s. 167. 
Wodociągi i Kanalizacja Sp. z o.o. Ścieki komunalne oraz przemysłowe z Koszalina trafiają do Oczyszczalni Ścieków w Jamnie, którą zmodernizowano w 2013 roku budując suszarnię odpadów.

Środowisko wodne na terenie Koszalina jest w stanie umiarkowano-dobrym (w stanie umiarkowanym - wody powierzchniowe, natomiast $\mathrm{w}$ stanie dobrym są wody podziemne).

\section{Projekty oraz programy realizowane na rzecz ochrony środowiska przez samorządy oraz miejskie spółki}

Projekty ekologiczne realizowane na terenie miasta Koszalina bardzo często nie są tylko projektami stricte ekologicznymi. Realizowane projekty uwzględniają nie tylko potrzeby mieszkańców związane z ochroną środowiska, ale także potrzeby komunikacyjne, mieszkaniowe, energetyczne, wypoczynkowe itd. Spośród wielu projektów zrealizowanych i realizowanych na rzecz ochrony środowiska należy zaliczyć:

- „Projekt optymalizacji systemu ciepłowniczego”: jest to inwestycja, realizowana przez Miejską Energetykę Cieplną sp. z o.o. Zakończenie prac przewidziane jest na 2015 rok, a wartość całego projektu zamknie się kwotą 26 mln złotych. Realizacja projektu polega na rozwoju infrastruktury technicznej w mieście, poprawie bezpieczeństwa dostaw ciepła oraz zmniejszaniu strat ciepła. Optymalizacja systemu ciepłowniczego przyniesie nie tylko korzyści wcześniej już wymienione, ale także pozytywnie wpłynie na stan środowiska naturalnego poprzez polepszenie stanu powietrza atmosferycznego w regionie.

- Ważnym zadaniem jest Zabezpieczenie przeciwpowodziowe zlewni jeziora Jamno wraz z rewitalizacją rzeki Dzierżęcinki. Celem realizacji tego przedsięwzięcia jest zwiększenie stopnia bezpieczeństwa powodziowego mieszkańców Koszalina oraz miejscowości i terenów przyległych do jeziora Jamno. Całkowity koszt inwestycji ma wynieść ok. 70 mln złotych, a jej zakończenie przewidziane jest na 2015 rok. Warto także podkreślić, że część środków przeznaczonych na inwestycję pochodzi z Unii Europejskiej, a dokładnie z Programu Operacyjnego Infrastruktura i Środowisko (tj. 23,7 mln).

- Dla mieszkańców i turystów ważnym była Rewitalizacja Parku Książąt Pomorskich.

W mieście realizowany jest Program Ochrony Środowiska Miasta Koszalina na lata 2012-2015 z uwzględnieniem perspektywy na lata 2016-2019. Głównym celem tego programu jest dążenie do sukcesywnej poprawy stanu środowiska natu- 
ralnego na terenie Koszalina oraz ograniczenie negatywnego wpływu zanieczyszczeń na środowisko, ochronę i rozwój walorów środowiskowych.

Do wielu programów wynikających z polityki ekologicznej państwa zaliczyć należy Program Ograniczenia Niskiej Emisji dla Miasta Koszalina (PONE), Program Usuwania Azbestu z Miasta czy Program Ochrony Środowiska Przed Hałasem.

W Koszalinie realizowane są też programy ogólnopolskie lub wojewódzkie, takie jak:

- Program Ochrony Środowiska Województwa Zachodniopomorskiego na lata 2012-2015 z perspektywą na lata 2016-2019,

- Krajowy Program Zalesiania Lesistości,

- Krajowy Plan Gospodarki Odpadami (KPGO 214),

- Wojewódzki Plan Gospodarki Odpadami dla Województwa Zachodniopomorskiego na lata 2009-2012 z perspektywą na lata 2013-2018,

- Krajowy Program Oczyszczania Ścieków Komunalnych,

- Program Rozwoju Turystyki.

Na podstawie opracowanych analiz, ocen środowiska, problemów środowiskowych opracowano szereg działań, które mają za zadanie osiągnięcie celów krótkoterminowych na lata 2012-2015 oraz celów długoterminowych na lata 2016-2019 dla każdego z komponentów środowiska naturalnego w Koszalinie. Opracowując konkretne działania uwzględniono obowiązujące i planowane zmiany przepisów prawnych, programy oraz strategie rządowe, wojewódzkie i regionalne. Program uwzględnia również, kto będzie odpowiedzialny za wykonanie danego działania oraz skąd będą pochodziły środki finansowe niezbędne do zrealizowania zadania. Program zakłada także, że co 2 lata będzie opracowywany raport, przedstawiany na posiedzeniach Rady Miejskiej.

\section{Inicjatywy organizacji społecznych na rzecz ochrony środowiska}

Inicjatywa społeczna (zwana również inicjatywą lokalną) to forma realizacji zadań publicznych przez administrację samorządową przy pomocy mieszkańców danego miasta, regionu itd.

Wśród inicjatyw społecznych coraz częściej podejmowane są inicjatywy ekologiczne. Inicjatywy te mają za zadanie zwrócenie uwagi na problemy ekologiczne, wspieranie działań mających na celu ochronę środowiska oraz promowanie proekologicznych postaw. Odbiorcami inicjatyw ekologicznych bardzo często są najmłodsi 
mieszkańcy. Na terenie Koszalina przedszkola oraz szkoły bardzo chętnie biorą udział w różnego rodzaju inicjatywach ekologicznych. Najbardziej popularna w mieście to inicjatywa Sprzątanie Świata - Polska.

Akcja jest częścią międzynarodowego ruchu na rzecz ochrony środowiska Clean up the World, która zapoczątkowana została w Australii w 1989 roku. W akcji tej uczestniczy blisko $40 \mathrm{mln}$ wolontariuszy w ponad 40 państwach. Akcja ta w Polsce została zapoczątkowana w 1994 roku przez Mirę StanisławskąMeysztowicz, założycielkę fundacji Nasza Ziemia ${ }^{12}$. Celem tej akcji jest przede wszystkim promowanie nieśmiecenia, edukacja odpadowa oraz podejmowanie innych inicjatyw na rzecz ochrony przyrody. Od 1994 roku w Polsce, w każdy trzeci weekend września setki wolontariuszy prowadzą działania, mające na celu propagowanie ograniczania powstawania odpadów poprzez selektywną zbiórkę odpadów oraz recykling. W trakcie realizacji tego projektu usuwane są także dzikie wysypiska śmieci. Działaniom tym towarzyszy cały wachlarz innych działań, m.in. sadzenie drzew, krzewów i kwiatów. Każdego roku akcji towarzyszy inne ogólnopolskie hasło. W 2012 roku hasłem przewodnim było: „Kocham, lubię, szanuję... nie śmiecę”. Z kolei w 2013 roku odbyła się jubileuszowa 20 edycja „Odkrywamy czystą Polskę". Głównym odbiorcą akcji w 2013 roku była młodzież szkół ponadgimnazjalnych. Tegoroczna edycja trwała od 19 września do 16 października, a jej hasłem przewodnim było: „Turysto! Szanuj środowisko”. Akcja ta ma zachęcić do refleksji nad wpływem ludzi na środowisko podczas wypoczynku lub pobytu na łonie natury. Organizatorem akcji na terenie Koszalina jest Urząd Miasta Koszalin, fundacja Nasza Ziemia oraz Nadleśnictwo Karnieszewice.

Ponadto Koszalinianie biorą udział w takich przedsięwzięciach jak:

- konkurs ekologiczny „Listy dla Ziemi” - jest to jedna z największych akcji ekologicznych w Polsce, która została zainicjowana przez Fundację Ekologiczną ARKA.

- bardzo popularną inicjatywą jest akcja „Mały przyjaciel lasu” - w akcji mogą brać udział dzieci z przedszkoli z Koszalina. Celem tego przedsięwzięcia jest szerzenie wiedzy o lesie i otaczającej nas przyrodzie oraz kształtowanie kultury ekologicznej. W ramach akcji były realizowane następujące zadania: sadzenie drzew, opiekowanie się zwierzętami oraz sprzątanie lasu.

Inicjatywy ekologiczne są nie tylko skierowane do najmłodszych, ale także do pozostałych mieszkańców Koszalina. Czasami takie akcje mają charakter charytatywno-ekologiczny. Przykładem takiej inicjatywy jest: akcja zbierania

\footnotetext{
${ }^{12} \mathrm{http}: / /$ naszaziemia.pl/programy/sprzatanie-swiata/cel-programu, 14.10.2014.
} 
nakrętek dla potrzebujących dzieci. Celem tych akcji, których w Koszalinie było już kilkanaście jest pomoc chorym dzieciom przy zakupie wózka inwalidzkiego lub sfinansowanie, rehabilitacji. Zadaniem takiej akcji jest nie tylko pomoc, ale także promowanie recyklingu.

Znane inicjatywy ekologiczne to akcja „Zgrani z naturą”, akcja „Sprzątajmy wokół naszych jezior i rzek". Inicjatywa ta służy ochronie wód i środowiska naturalnego. Interesujące przedsięwzięcia to także ekologiczny konkurs fotograficzny „Nietypowe zjawisko” lub happening „Odpady pod kontrolą”.

$\mathrm{Na}$ terenie miasta Koszalina ma miejsce wiele inicjatyw społecznych, których głównym zadaniem jest ochrona środowiska oraz propagowanie postaw proekologicznych. Inicjatywy ekologiczne są bardzo pozytywnym zjawiskiem, ponieważ zmieniają mentalność ludzi oraz ich postawy względem środowiska naturalnego.

\section{Podsumowanie}

Marketing ekologiczny jest zjawiskiem stosunkowo nowym. Jest to koncepcja, której głównym założeniem jest poszukiwanie odpowiedzi na proekologiczne potrzeby społeczeństwa. Marketing ekologiczny zwraca także uwagę na problem ochrony środowiska naturalnego oraz pozwala zwiększać poziom świadomości ekologicznej społeczeństwa. Podejmowanie działań w ramach ekomarketingu jest również dobrym sposobem na promowanie i kreowanie pozytywnego wizerunku przedsiębiorstw, instytucji publicznych oraz miast czy regionów.

Marketing ekologiczny jest niezbędny w inicjowaniu oraz podejmowaniu nowych inicjatyw, mających za zadanie ochronę środowiska naturalnego. Dzięki marketingowi ekologicznemu przedsiębiorstwa, instytucje publiczne oraz organizacje społeczne wiedzą, jakie działania muszą zostać podjęte, aby zostały zaspokojone potrzeby ekologiczne mieszkańców. Można więc stwierdzić, że ekomarketing jest impulsem do realizacji inicjatyw proekologicznych.

\section{Bibliografia}

Castenow D., Nowy marketing w praktyce, PWE, Warszawa 1996.

http://naszaziemia.pl/programy/sprzatanie-swiata/cel-programu, 14.10.2014.

Kiełczewski D., Ekologia społeczna, Wydawnictwo Ekologia i Środowisko, Białystok 1999.

Kotler Ph., Marketing. Analiza, planowanie, wdrażanie i kontrola, Gebethner i S-ka, Warszawa 1994.

Małachowski K. (red.), Gospodarka, a środowisko i ekologia, CeDeWu, Warszawa 2011. 
Program Ochrony Powietrza Dla Stref Województwa Zachodniopomorskiego, tj. aglomeracji szczecińskiej, miasta Koszalin oraz strefy zachodniopomorskiej - TOM III - STREFA MIASTO KOSZALIN, 2013 r., http://eregion.wzp.pl/sites/default /files/iii_pop_strefa_koszalin.pdf, 14.10.2014.

Program Ochrony Środowiska Przed Hałasem Dla Miasta Koszalina, 2013, http://www.bip.koszalin.pl/?a=17600, 14.10.2014.

Piontek F. (red.), Ekonomia, a zrównoważony rozwój, t. 2, Wydawnictwo Ekonomia i Środowisko, Białystok 2001.

Przybyłkowski K., Marketing, Dom Wydawniczy ABC, Warszawa 1998.

Zaremba-Warnke S. (red.), Marketing ekologiczny, Wydawnictwo Uniwersytetu Ekonomicznego we Wrocławiu, Wrocław 2009.

\section{Selected aspects of the use of ecological marketing for improving natural environment in Koszalin}

\section{Summary}

The article presents the essence of ecological marketing and characterizes selected environmental problems in the town of Koszalin. The hazards due to emissions of undesirable substances, noise, waste management and water-sewer management are described. While analysing the condition of the environment, a review of major environmental initiatives taken by the local authority, municipal companies and social organizations was carried out.

Translated by: Włodzimierz Deluga 